\title{
LEBANON
}

There have been quite a number of accounts in recent issues of International Review of the efforts to bring assistance to the victims of the hostilities in Lebanon. This time, it would like to pay tribute to the members of the Lebanese National Red Cross Society for the work, often on a modest scale but always worthy of the greatest admiration, which they carry out, despite great danger and enormous difficulties, in remote places cut off from the larger centres. These activities are an eloquent testimony to the splendid Red Cross spirit which the Lebanese Red Cross, fired by the zeal of its President, Mrs. A. F. Issa el-Khoury, instilled in its members, even before the clashes had begun.

We also wish to extend this tribute to the members of the "Palestinian Red Crescent". This organization has not been accorded recognition but, under the leadership of its President, Dr. Fathi Arafat, its members have been showing extraordinary devotion and efficiency.

Here are two instances of their activities described by a press attachée of the ICRC, Miss F. Bory, who was lately in Lebanon.

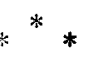

There were joyful scenes in the local branch of the Lebanese Red Cross at Antelias, a village near Jounieh and not far from Beirut, in a predominantly Christian area.

Its members were getting ready the blankets, donated by the ICRC, for distribution to about one hundred and twenty needy families who sorely needed protection against the cold. This was already cause enough for joy, but the main reason was the unexpected arrival of another member of the Lebanese Red Cross, a Muslim, come to join the Christian members in their task. Only a few days before, such an event would have been unthinkable. Could this be a good omen of peace to come?

In the area east of Beirut, near Jounieh, many thousands of displaced Christians live in distressful conditions. When fighting flared up in southern Lebanon, they fled their villages and settled down where danger seemed less likely. At first they were housed in schools, but now that the situation is returning gradually to normal and classes are 

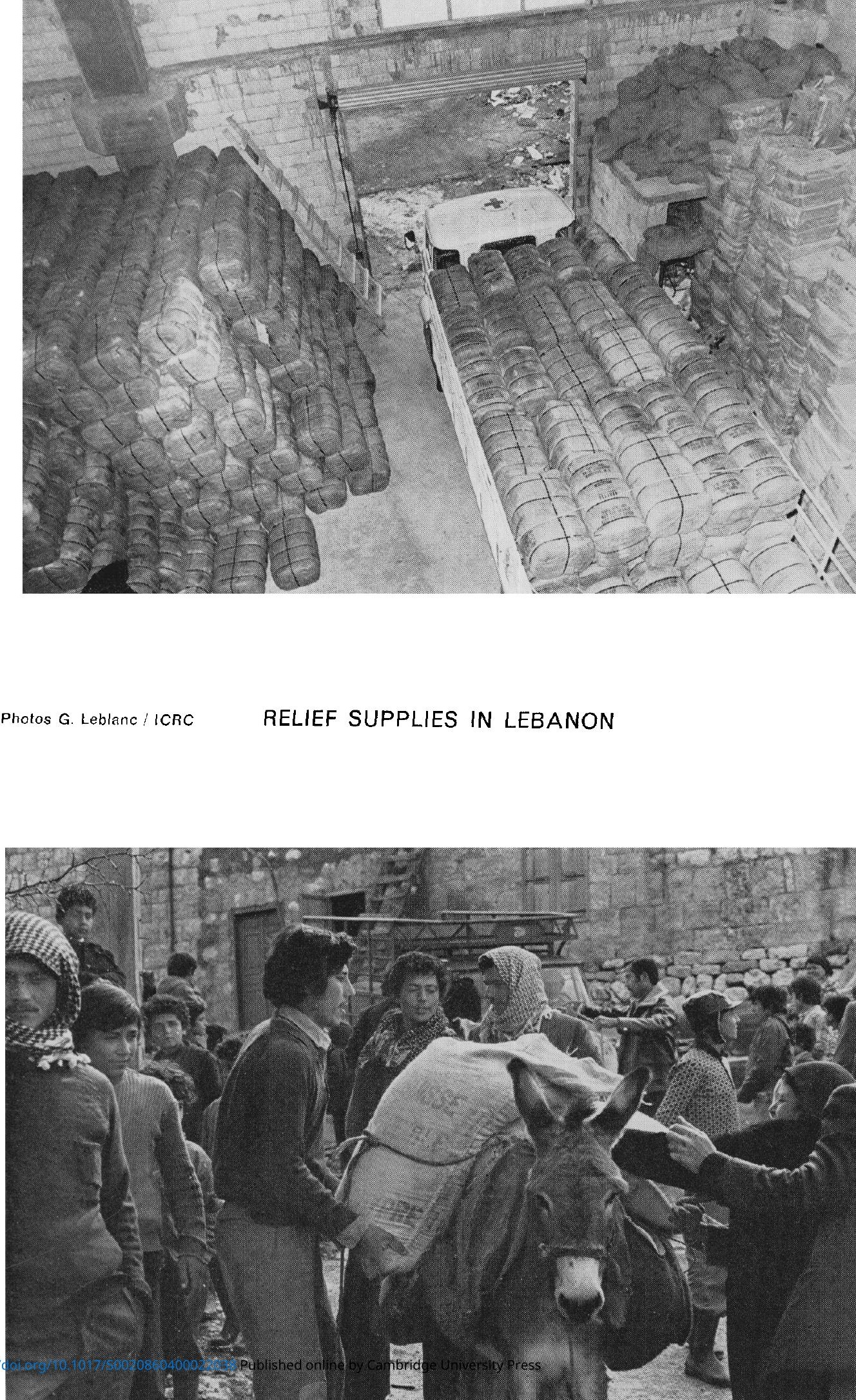
reopening, after two years, they will have to go elsewhere. Some families find accommodation with relatives, others in homes abandoned by their former occupants. For them all, the winter is harsh; not for many years has Lebanon gone through a period of such severe cold. The blankets will therefore be extremely welcome.

As soon as the ICRC lorry drew up in front of the Lebanese Red Cross station, willing hands started to unload the bales of blankets and carry them into a large room-in normal times the dispensary's waitingroom - where five tables had been set up, with notice boards bearing the names of the recipients' villages. Soon the room was filled with a bustling crowd: old men wearing baggy trousers and sporting impressive-looking mustachios, women swathed in large shawls surrounded by children. For the remainder of the time, there was a continuous chatter of repeated explanations, cheerful talk and information, as the Red Cross volunteers, their faces wreathed in smiles, went on handing out the blankets until they were all distributed.

$$
* * *
$$

At the edge of Chattila Camp, near Beirut's international airport, the "Palestinian Red Crescent" hospital kept open all the time the fighting continued. At present, it is being extended to house departments of other hospitals destroyed in the fighting. In one of the recently-built wards, a workshop for the production of orthopedic prostheses has been opened, with a complete set of physiotherapy equipment. All the equipment has not yet been fitted but work is already in progress.

On the day of our visit we found several patients in the waitingroom. The "Palestinian Red Crescent" gives free treatment to all who come, Palestinians, Lebanese, Muslims, Christians, without distinction of any sort.

In the prosthesis workshop there may still be a shortage of tools and materials but there is certainly plenty of enthusiasm. About a dozen young men were working away, with their unsophisticated equipment, with planes and other handtools, making artificial arms and legs, and turning out two to three artificial limbs a week.

The craftsman at the head of the team is a Lebanese who worked for twenty years in an orthopedic centre in the mountains above Aley. "When the place where I worked was destroyed in the war", he said, "I came to Beirut and asked at the hospital here if I could be of any use".

His request to make himself useful will certainly be fulfilled: about a dozen amputees come every day to the centre for measurements to be taken, casts to be made, or for trial fittings. 
The number of patients is expected to rise; announcements are being broadcast on radio and television for all disabled to come forward. At the same time, various kinds of material, mainly surgical plastic and resin and other equipment, will soon be sent by the ICRC, and specialists to reinforce the Lebanese team.

ICRC aid will be extended to the paraplegics, who are in need of wheelchairs and medical care. There is also a demand for artificial eyes which, while they do not restore sight, at least give the patient a more natural appearance and help him to have more confidence in life.

\section{APPEAL TO NATIONAL RED CROSS SOCIETIES}

The International Review wishes to give its readers every month, under the heading "In the Red Cross World", reports on the organization and principal activities of the National Red Cross Societies.

To do this, the editor uses the documents he has available, such as reports by delegates and brochures and periodicals published by the Societies.

The Review would like to go beyond this and publish texts written by the Societies themselves. It therefore asks Red Cross Societies to send texts, and if possible photos, dealing with their main activities, their problems and their plans for the future. The Review is convinced that its readers would be greatly interested in such material, which would certainly contribute to the exchange of ideas and enable each Society to benefit from experience elsewhere.

\section{TWENTY-THIRD INTERNATIONAL CONFERENCE OF THE RED CROSS}

In its January 1977 issue, the International Review of the Red Cross published the provisional programme and agenda of the twenty-third International Conference of the Red Cross, to be held at Bucharest from 15 to 21 October 1977. Previously, starting on 4 October, various other meetings will take place: the Board of Governors, the Council of Delegates and other bodies of the League of Red Cross Societies.

In January, the Red Cross of Romania sent notices of convocation to the States signatories to the Geneva Conventions, to recognized National Societies, and to the International Committee of the Red Cross and the League of Red Cross Societies, all of which are full members of the Conference. Invitations were also sent to a number of observers. 